\title{
On the development of methods for assessing project financing risks
}

\author{
Natalia Voronina* and Svetlana Steksova \\ Pacific State University, 680035, Khabarovsk, Russia
}

\begin{abstract}
The introduction of new methods for industrial infrastructural development and the methods of financing has led to the emergence of a promising direction - project financing. The development of project financing in the Russian Federation is primarily associated with a change in legislation, within the framework of which a system of escrow accounts was introduced in order to preserve the funds of equity holders. The gradual transition from the traditional equity participation scheme to project financing should contribute to the development of the construction industry, increased business activity and an increase in construction volumes. However, the limiting factor in the development of this area is the high risks for all participants in the investment and construction process and the lack of an effective method for assessing the risks of project financing. The development of this method is complicated by the fact that along with the general and characteristic risks of all investment projects, each project has its own characteristics, specific contractual and financial structure and implementation conditions and is associated with industry and regional risks inherent in this particular project. In this regard, the development of methods for assessing the project financing risks is one of the tools for making timely management decisions on the part of the developer to optimize the investment and construction process. This will allow attracting additional resources to the investment and construction sector and increasing the volume of housing construction.
\end{abstract}

\section{Introduction}

Risk assessment of investment projects is still a difficult problem in the practice of real investment. The development of forms and methods of project financing has complicated this task, since the new subjects of investment activity have appeared, participating in the project implementation and requiring consideration of their interests. This, in turn, is reflected in the general project risks' redistribution. In addition, the new forms of financing bring new risks. In this regard, the development of methods for assessing the project financing risks based on an integrated approach and taking into account the specifics of the project can be considered as one of the ways to increase the investment and construction activities' efficiency.

\footnotetext{
* Corresponding author: nat_vnv@mail.ru
} 
The system of quantitative assessment of project risks, developed by the authors, taking into account its specifics, will make it possible to make timely and well-grounded management decisions in the implementation of projects based on project financing. The scientific novelty of the research lies in the consideration of the project as an unstable spatial-temporal system of resource allocation with the allocation of life cycle periods and points of management decision-making and the development on this hypothesis of an integrated system for assessing the risks of project financing, taking into account the project financial viability.

\section{The current state of research analysis in this area}

General theoretical issues of project financing are detailed in the works of Ph. Benoit [1] and E.R. Yescombe [2]. Along with the consideration of the general methodological principles of project financing, the authors paid considerable attention to the classification and identification of the risks of projects implemented on the basis of project financing. Among the works devoted to project financing in Russia, it is necessary to note the works of V.Yu. Katasonov [3], D.S. Morozov [3], M.V. Petrov [3], I.I. Rodionov [4], R.N. Bozhya-Volya [4]., A.L. Smirnov [5, 7], I.A. Nikonova [6, 7], A.E. Barinov [8], V.N. Shenaev, [9], B.S. Irniyazov [9], I.I. Mazura [10], Ya.S. Melkumov [11]. They systematize modern methods and concepts used in project financing, consider various risks and methods to reduce them, including the use of escrow accounts in international practice. The works also pay great attention to the distinctive features of "classical" project financing and provide examples of the practical use of project financing schemes abroad.

Project financing as a way of lending to investment projects is considered in the works of V.Yu. Katasonov, V.N. Shenaev. In the works of D.S. Morozov, M.V. Pertov, special attention is paid to the risks arising from the implementation of large investment projects and ways to minimize them. The problems and risks that banks may face when they provide loans on the project financing principles in Russia are discussed in detail in the work of $\mathrm{T}$. Belikov [12]. The financing process, spread over time, requires a risk assessment at each stage of the project life cycle - from the moment of its preliminary feasibility study to the completion moment. Consideration of risks at the stages of project implementation was undertaken in the works of D.V. Abramov [13], A.V. Kazansky [14].

Mathematical models of various types of uncertainty characteristic of investment projects are presented in the work of S.A. Smolyak [15].

Despite a large number of publications and a high level of theoretical substantiation of project financing, insufficient attention is paid to the formation of an integral effective risk management system, there are ambiguous formulations of this concept. Also, many methodological issues related to the use of modern risk assessment tools in the framework of project financing have not been resolved. Additional research is needed in this direction, which will expand the use of project finance practice in Russia.

\section{Results}

An additional impetus for the development of project financing is associated with the amendments to the Federal Law 214-FL "On participation in the shared construction of apartment buildings and other real estate and on amendments to some legislative acts of the Russian Federation", which obliged the developers to use escrow accounts from 01.07.2019. The new amendments imply a transition from equity to project financing, that is, from a direct receipt of funds to the developer when purchasing housing in houses under construction to the transfer of funds using escrow accounts [16]. A phased transition to 
project financing for housing construction should help solve the problems of defrauded equity holders and reduce investment risks, which were divided into three stages in terms of deadlines. At the first stage, regulatory and legal documents were developed, as well as amendments were made to some of them, regulating the mechanism of project financing [17]. During the first year of the transition period - from July 1, 2018 to July 1, 2019 - it was allowed to enter into transactions both under equity participation agreements and using escrow accounts. And already from July 1, 2019, all the organizations involved in the construction of housing with the involvement of individual funds had to switch to the project financing scheme, that is, using escrow accounts opened in authorized banks [18]. The third and final stage has been extended until the end of 2021. The introduction of a phased mechanism for the transition to project financing is presented in Table 1.

As a part of the study to identify the project financing risks, a survey among participants in the investment and construction activities of the Khabarovsk Territory at the initial stage of project financing implementation was conducted (2018-2019) and at the final stages (2020-2021). All survey participants were divided into several groups - investors, developers, customers, home buyers, credit organizations, as well as design companies. At the initial stages of organizing project financing, before the introduction of shared construction of escrow accounts into practice, about $70 \%$ of participants in investment and construction activities assessed the risk of project financing as very high. However, in 2020-2021, when only the project financing scheme began to be used in housing construction financing, the situation changed dramatically, most of the surveyed participants in the investment and construction market noted a decrease in risk. Only $36.8 \%$ rated the risk as high and $36.8 \%$ as medium. However, the overall reduction in the risks of housing projects using escrow accounts does not mean that every project is inevitably doomed to success.

The implementation of projects on terms of project financing is characterized by a fairly high level of uncertainty and is subject to the influence of factors of the internal and external environment. Partially the negative impact of factors is taken into account in assessing the magnitude and occurrence probability of the corresponding type of project risk. However, the high level of financial and economic risks, expressed in terms of project lending, its financial results, the possibility of self-financing and solvency, makes it necessary to take into account its financial solvency in a comprehensive risk assessment of a project. Upon receipt of project financing for housing construction, the borrower of credit resources is not a project company, as in the classical project financing scheme, but an operating construction organization - a "specialized developer". In this regard, when considering an application, the company experience, creditworthiness, and the possibility of collateral come to the fore. But at the same time, credit funds are issued for a specific investment project, the return of which must be secured by future cash flows. Due to the future events' uncertainty, the risk of this financing increases for all parties to the transaction occurs. In this regard, the analysis of the financial viability of investment projects is not only a necessary procedure for opening a credit line for project financing, but also for substantiating the sustainable operation of a construction company, which in turn will reduce project risks.

This approach is implemented in the algorithm developed by the authors for calculating the total risk of a project, taking into account its financial and economic condition.

Table 1. Implementation of a phased mechanism for the project financing implementation.

\begin{tabular}{|c|c|c|c|c|c|c|}
\hline 2018 & $\rightarrow$ & 2019 & $\rightarrow$ & 2020 & $\rightarrow$ & 2021 \\
\hline$\downarrow$ & & $\downarrow$ & & $\downarrow$ & & $\downarrow$ \\
\hline Creation of a & & Conclusion of an & & Only the escrow & & Only escrow \\
\hline
\end{tabular}




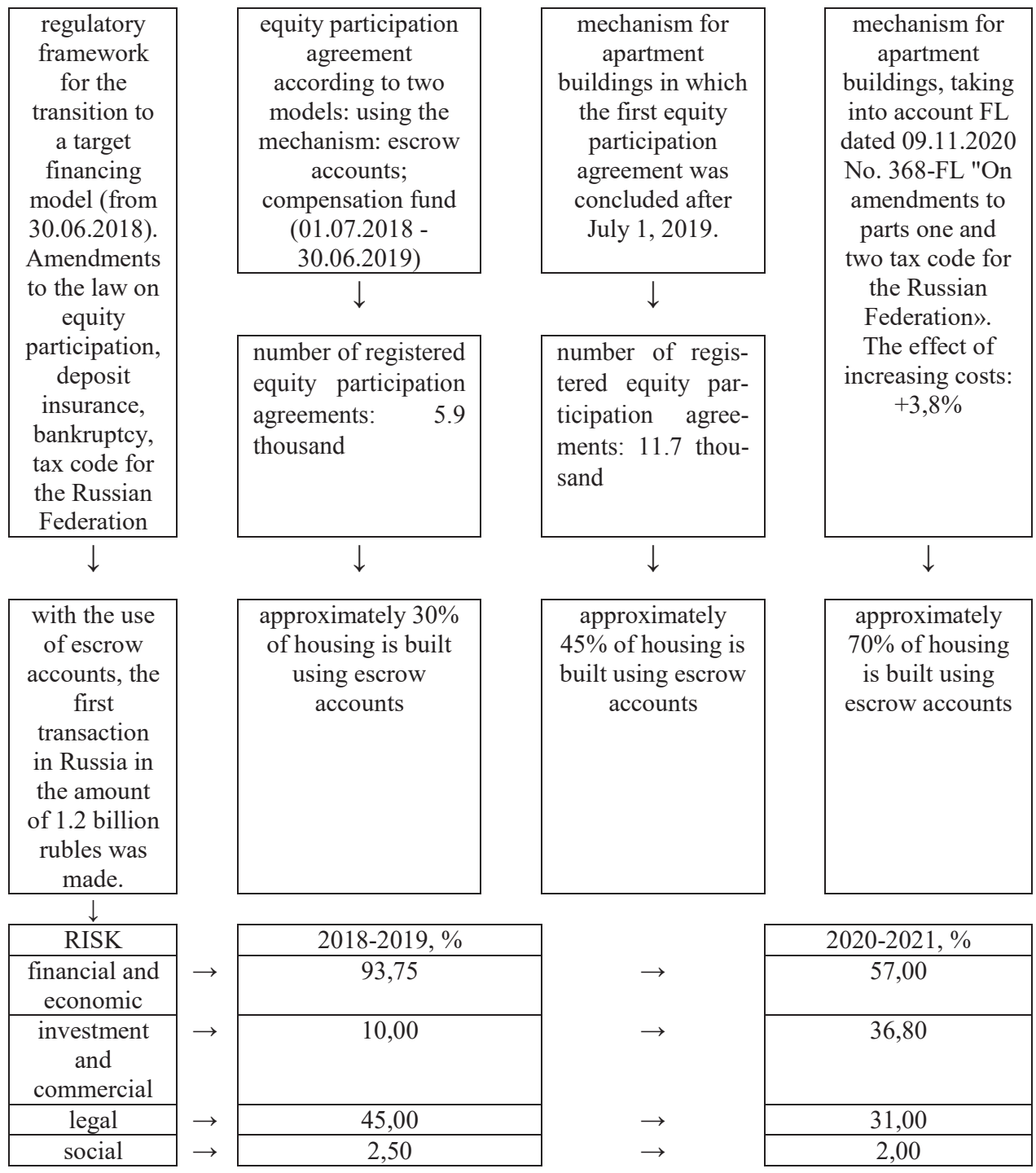

At the first stage, it is necessary to calculate the total risk of an investment project, which is the sum of the project private risks, taking into account the likelihood of their occurrence.

$$
R_{\text {totl }}=\sum_{i=1}^{n} R_{i} \times p_{i}
$$

where $R_{\text {total }}$ - is an aggregate risk of an investment project; $R_{i}$ - is the value of the $\mathrm{i}$-th type of risk of an investment project; $p_{i}$ - is the probability of the i-th type of an investment project risk occurrence; $n-$ is the number of identified risks.

The value for the $\mathrm{i}$-th type of risk is calculated using the following formula:

$$
R_{i}=\frac{\sum_{i=1}^{m} r_{i} * b_{i}}{\sum_{i=1}^{m} b_{i}}
$$


where $m$ - is the number of indicators characterizing the i-th type of risk; $r_{i}$ - is the numerical value of the indicator of the i-th type of risk; $b_{i}-$ is the weight of the $\mathrm{i}$-th indicator.

At the second stage, it is necessary to calculate the project financial viability indicators. There is a fairly large number of indicators characterizing the financial and economic state of the project. These can be traditional financial ratios, complex integral indicators, as well as the cost ones. As indicators characterizing the financial and economic state of the project, the authors propose to use financial ratios, as the most objective, informative and comparable. As such indicators, the following can be proposed: the autonomy ratio, the total return on assets ratio, the current liquidity ratio, the absolute liquidity ratio, the return on sales ratio, the asset turnover ratio, the equity ratio.

All actual values of indicators are converted into standardized ones in order to eliminate the influence of differences in the composition of the aggregate estimate. The calculation is made according to the formula:

$$
\mathrm{K}_{\text {stand }}=\frac{\mathrm{K}_{\text {fact }}}{\mathrm{K}_{\text {marm }}},
$$

where $K_{\text {stand }}-$ is a standardized financial ratio; $K_{\text {fact }}-$ is an actual coefficient value; $K_{\text {norm }}$ - is a standard (recommended) coefficient value.

Coefficient value $K_{\text {stand }}$ more than 1 indicates the excess of the actual value of the coefficient over the recommended.

The complex integral coefficient of the financial viability of the project (KF) is presented in the form of a multiplicative model and is calculated by the formula:

$$
K F=\prod_{i=1}^{n} K_{\text {stand } i}
$$

where $K_{\text {stand } i}$ - is the standardized value of the $\mathrm{i}$-th financial ratio; $n-$ is the number of coefficients involved in the calculation.

Since the coefficients included in the model are unidirectional, the product of standardized coefficients more than 1 indicates a satisfactory financial and economic state of the project.

At the third stage, the indicator of the project total risk is calculated, taking into account its financial and economic condition $\left(\mathrm{R}_{\text {correct }}\right)$, as the ratio of the total risk of the project to the complex integral indicator of the project financial viability.

$$
R_{\text {correct }}=\frac{R_{\text {total }}}{K F}
$$

The projects with a high level of financial stability, sufficient liquidity and solvency, as well as profitability have high chances of successful implementation and preferential terms of lending from the bank. This, in turn, helps to reduce the risk of the project as a whole, its attractiveness for potential buyers and investors.

\section{Conclusion}

Recent changes in the legislation governing the field of housing construction have given a new impetus to the project financing practice development in the Russian Federation. Not only new legal relations have appeared, but also the subjects of investment and construction activities. All this contributes to the further formation of the project financing fundamental principles, the development of methodological approaches to assessing risks and mechanisms to reduce them, taking into account localization, as well as the manifestation peculiarities. Taking into account the financial viability of an investment project when 
assessing the risk of project financing will increase the objectivity of decision-making on the implementation of such projects.

\section{References}

1. Benoit Philippe, Project Finance at the World Bank. An Overview of Policies and Instruments. - World Bank Technical Paper Number 312, The World Bank. Washington, D.C., 1996.

2. E.R. Yescombe, Principles of project finance. Per. from English (Alpina Publisher, M., 2016)

3. V.Yu. Katasonov, D.S. Morozov, M.V. Petrov, Project financing: world experience and prospects for Russia (Ankil, M., 2001)

4. I.I. Rodionov, R.N. Bozhya-Volya, Project financing (Aletheia, St. Petersburg, 2015)

5. A.L. Smirnov, Project financing: tools and technologies: Monograph (MAKS Press, Moscow, 2013)

6. I.A. Nikonova, Project analysis and project financing (Alpina Publisher, M., 2010)

7. I.A. Nikonova, A.L. Smirnov, Project financing in Russia. Problems and directions of development (Consultbankir, M., 2016).

8. A.E. Barinov, Project financing. Technologies for financing investment projects (Os89 Publishing House, Moscow, 2009)

9. V.N. Shenaev, B.S. Irniyazov, Project lending. Foreign experience and the possibility of using it in Russia (Consultbanker, M., 1996)

10. I.I. Mazur, Investment and construction engineering: A guide for professionals (Omega-L, M., 2010)

11. Ya.S. Melkumov, Organization and financing of investments (Infra-M, M., 2002)

12. T. Belikov, Mine fields of project finance: A survival guide for loan officers and investors (Alpina Publisher, M., 2009)

13. D.V. Abramov, Methods of risk management in the organization of project financing in Russia, (2009)

14. A.V. Kazansky, Problems of modern economics 1 (53), (2015)

15. S.A. Smolyak, Evaluation of the effectiveness of investment projects in conditions of risk and uncertainty: Theory of the expected effect (Internet version), (2012) http://sasmolyak.socionet.ru/files/BOOK2012.pdf (Access date: 25.03.2021).

16. Escrow accounts for legal entities: legal guide AllZakon, 12.11.2018, https://allzakon.ru/zakon/ccheta-eskrou-dlya-yuridicheskih-lits.html (Access date: 25.03.2021).

17. L.Sh. Gimadieva, Bulletin of Eurasian Science, 2, (2019) https://esj.today/PDF/77ECVN219.pdf (free access) (Access date: 25.03.2021).

18. Indicative Analysis of the Impact of Switching to Escrow Accounts for a Typical Residential and Integrated Residential Development Project, Study: Roscongress Trust Space, 18.09.2019. https://roscongress.org/materials/indikativnyy-analiz-vliyaniyaperekhoda-na-mekhanizm-eskrou-schetov-dlya-tipovogo-zhilogo-proekta-i-/ (Access date: 01.03.2021). 